Classification of the Animal Kingdom", and medical science by one on "The Nature and Treatment of Sclerosis", a process terminating in hardening and calcification in tissues and organs. The latter presents the subject largely from a metaphysical and homøopathic point of view, and cannot be accepted as representing modern medical conceptions. The metaphysical also looms large in "Alterations in the Earth's Surface", and so far as science is concerned, the articles can scarcely be accepted as representative of its modern aspects.

\section{New Garden Plants}

THE present generation of horticulturists is fortunate in the ever-increasing number of new contributions to garden beauty. Scientific hybridisation and selection have produced more pleasing shades of bloom, or enhanced symmetry of form from old favourites, whilst ardent botanists roam amongst the wilder parts of the world to find new grandeur for the rockery or herbaceous border. Plants from these sources which have stood the test of English cultivation are described ( $J$. Roy. Hort. Soc., November) by Dr. Fred Stoker, who writes on "Ericaceous Plants" and Mr. Ben Wells, who discusses herbaceous subjects. Both accounts are well illustrated with excellent half-tone plates, and give many practical details.

\section{Memorandum on Pneumonia}

PNEUMONTA, as a cause of national mortality, has long been a matter of concern to public health authorities. In 1934, for example, this disease was responsible for 28,623 deaths in England and Wales, and in times of influenza prevalence the martality may reach a much higher figure. The Ministry of Health has, therefore, issued a Memorandum (Memo. 189 Med.) with covering circular (No. 1499) on the subject for the use of public health authorities, in which the classification and bacteriology, its prophylaxis and the general administrative measures applicable, are dealt with (H.M. Stationery Office. ld. net).

\section{Physical Society's Exhibition}

THE twenty-sixth annual exhibition of scientific instruments and apparatus arranged by the Physical Society opens at the Imperial College of Science and Technology on January 7. The times of admission are 3-6 and 7-10 p.m. (January 7), 2-4, 4-6 and 7-10 p.m. (January 8) and 3-6 and 7-10 p.m. (January 9). A descriptive catalogue of the exhibits can be obtained from the Exhibition Secretary, Physical Society, I Lowther Gardens, Exhibition Road, London, S.W.7 (1s. post paid), to whom applications for tickets of admission should also be addressed.

\section{Indian Science Congress Association}

THE twenty-third annual meeting of the Indian Science Congress Association is being held on January 2-8 at Indore, under the presidency of Rai Sir Upendranath Brahmachari Bahadur. The presidents of sections are as follow: (1) Mathematics and Physics: Dr. T. Royds, director of the Kodaikanal Observatory ; (2) Chemistry: Dr. P. C. Guha, professor of organie chemistry, Indian Institute of Science, Bangalore; (3) Geology and Geography: B. Rama Rao, officiating director of geology, Mysore Geological Department, Bangalore ; (4) Botany: Dr. S. R. Bose, professor of botany, Carmichael Medical College, Calcutta ; (5) Zoology: Dr. H. K. Mookerjee, University professor and head of the Department of Zoology, University of Calcutta ; (6) Anthropology: H. C. Chakladar, lecturer in anthropology, University of Calcutta; (7) Agriculture: A. K. Yagna Narayan Aiyer, formerly director of agriculture, Sankarapuram, Bangalore ; (8) Medical and Veterinary Research: Lieut.-Col. H. E. Shortt, director of the King Institute, Guindy, Madras; (9) Physiology: Dr. W. Burridge, professor of physiology, University of Lucknow ; (10) Psychology : J. M. Sen, inspector of schools, Presidency Division, Bengal.

\section{Recent Meteors and Fireballs}

The Meteoric Display of November 21. A letter has been received from Mohd. A. R. Khan, whose wireless message was published in NATURE of November 30, p. 867, as follows: "I observed over one hundred meteors between $6 \mathrm{~h} .50 \mathrm{~m}$. and $7 \mathrm{~h} .10 \mathrm{~m}$. G.M.T. on November 21, of which several were of first magnitude with long trails. Eleven more were observed in the next 20 minutes. The sky was rather hazy. Perhaps the richest part of the shower occurred somewhat earlier, before I began observation". The possible return of this shower should be looked for by meteor observers in future yoars.

A great Detonating Fireball. On November 25, at $0 \mathrm{~h} .20 \mathrm{~m}$. U.T., a meteor which announced its arrival with a 'blinding glare of light' was observed in south-west England by many people. At Bridgwater there was a loud explosion after the disappear. ance of the fireball, "followed by a rumbling noise resembling thunder, lasting for about a minute". Heavy detonations were also heard at Weston-super. Mare and Bristol. Mr. A. King, of 53 Victoria Road, Ashby, Scunthorpe, Lincs, has received some ten accounts, but they are mostly so vague (and in some cases contradictory) that a definitive real path cannot be computed. All that can be said in this respect is that the object passed over the district between Bridgwater and Bristol at a low height.

Daylight Firebali. On December 3, at 1lh. 30m. U.T., an observer in Bradford saw a meteor with a long tail shoot across the eastern sky. This must have been a very fine fireball. Observations of the fireball should be sent to Mr. King.

\section{Announcements}

THe Catherine Wolfe Bruce Gold Medal for 1936 of the Astronomical Society of the Pacific has been awarded to Prof. A. O. Leuschner, professor of astronomy and director of the Students' Observatory in the University of California, for distinguished services in astronomy. Prof. Leuschner is an authority on the determination of the orbits of planets. 
THE Prix Binoux of 1935 for the history and philosophy of science has been awarded by the Paris Academy of Sciences to Dr. George Sarton, editor of Isis and associate of the Carnegie Institution, for the published volumes of his "Introduction to the History of Science". This is the second time that the French Academy has awarded the Prix Binoux to Dr. Sarton ; it was first awarded to him in 1915 .

Dr. E. C. Bullard has been appointed Smithson research fellow of the Royal Society as from January 1. Dr. Bullard proposes to continue his present work on the development of methods of measurement and their application to geological problems, in the Department of Geodesy and Geophysics of the University of Cambridge. This work includes the explosion method of studying geological structure. The first problem in this connexion will be the determination of the depth of the Palæozoic rocks under eastern England. It is also hoped to develop methods for the measurement of heat leaving the earth per unit area and its variation from place to place.

The Right Hon. Lord Rutherford will deliver the sixteenth Faraday Lecture of the Chemical Society in the lecture theatre of the Royal Institution on February 12, at 5.30. The subject of Lord Rutherford's lecture will be "Radioactivity and Atomic Theory".

Mr. A. Hanpton Brown has retired from the position of assistant secretary of the Royal Meteorological Society after serving on the office staff for forty years. Miss E. N. Kidner has been appointed to succeed him as assistant secretary.

THE arrangements made for the transfer of apparatus from the Royal Society Mond Laboratory at Cambridge to a new laboratory which is being built for Prof. P. Kapitza in Moscow were described in a paragraph in NATURE of November 23, 1935, p. 825 . The new laboratory is not yet in a working condition, but friends of Prof. Kapitza in many parts of the world will be interested to know that his address is now, Institute for Physical Problems, Kaloujskoe Shosse 24, Moscow, U.S.S.R.

A LARGE earthquake was recorded at Kew Observatory on December 28. The first impulses reached Kew at 2 hr. $48 \mathrm{~min} .56 \mathrm{sec}$, and the record indicates that the shock originated 6,300 miles away, apparently near the northern end of Sumatra.

A CORRESPONDENT writes to us: "Now that our Teutonic colleagues have abandoned the clumsy and unpatriotic word $M i k r o s c o p$, it is to be presumed that we shall no longer be harassed by the barbaric term Binokular? Heil, Doppelaugigenbenützbar Kleinsehwerkzeug! How much more neat and appropriate" !

A MARBLE plaque has recently been affixed to the birthplace at Villeneuve-le-Guyard of Prof. Chauveau, who was born there in 1827 and died in Paris in 1917.
At the time of his death, he was a member of the Academy of Medicine, honorary professor of the Veterinary School at Lyons, professor at the Paris Museum, inspector of the French Veterinary Schools and Grand Officer of the Legion of Honour.

PART 3 of the classified catalogue of books in the Library (including Departmental Libraries) of the London School of Hygiene and Tropical Medicine has been issued. It is compiled by the librarian, Mr. Cyril Barnard, and includes the literature in Classes E, F and G, dealing with epidemiology, vital statistics and medical geography; ætiology, diseases of doubtful causation and those due to physical agents; toxicology and diseases of chemical causation.

The Cambridge University Press will shortly publish in the Craftsman Series, "James Watt, the Craftsman", by Mr. H. W. Dickinson. Other writers have dealt with his career as an inventor, but, as Mr. Dickinson's book shows, Watt's craftsmanship is an equally interesting aspect of his character. It was a faculty that stood him in good stead as an inventor, and it turned out to be the solace of his old age. This book comes opportunely; the bicentenary of Watt's birth falls in 1936.

Applications are invited for the following appointments, on or before the dates mentioned :

A teacher of mathematics and physics in the Northampton Polytechnic, St. John Street, London, E.C.1 (Jan. 10).

Assistants (Grade III) in the Directorate of Technical Development of the Air Ministry-The Chief Superintendent, Royal Aircraft Establishment, South Farnborough, Hants (Jan. 11).

Technical assistants (physies or engineering) in a War Department Establishment at Woolwich-The Superintendent, Signals Experimental Establishment, Woolwich Common, S.E.18 (Jan. 13).

An assistant (III) at the Forest Products Research Laboratory, Princes Risborough-The Establishment Officer, Department of Scientific and Industrial Research, 16 Old Queen Stroet, Westminster, S.W.1 (Jan. 15).

An agricultural instructor for the administrative County of the Isle of Ely-The Director of Education, Education Department, County Hall, March (Jan. 17).

A senior scientific officer at the Royal Aircraft Establishment, South Farnborough, Hants-The Chief Superintendent (Jan. 17).

A guide lecturer in the Geological Survey and Museum, Exhibition Road, S.W.7-The Director (Jan. 28).

A cartographer in the Hydrographic Department of the Admiralty-The Secretary, Civil Service Com. mission, Burlington Gardens, W.1 (Feb. 20).

A male vocational guidance officer in the National Institute of Industrial Psychology, Aldwych House, W.C.2-The Secretary. 